\title{
National Consciousness and Management of Secondary Education for Sustainable Development in Kwara State, Nigeria
}

\author{
Abdullahi Nimota Jibola Kadir ${ }^{1}$, Isiaka Babatunde Akanmu ${ }^{2}$, Atolagbe \\ Adedapo Adetiba ${ }^{3}$, Etejere Patricia Agnes Ovigueraye ${ }^{4}$
}

\section{Abstract}

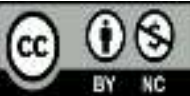

National consciousness within educational institutions could enhance effective management of education for sustainable development. This study examines the existing relationship between cultural integration, sports activities, gender equality and management of secondary education for sustainable development in Nigeria. Stratified random sampling technique was used to select 175 principals from a population of 310 principals and 364 teachers from a population of 6,894 teachers in public senior secondary schools in Kwara State, Nigeria with the use of Research Advisor (2006) table to determine sample size of a known population making a total of 539 participants. Data were collected using the National Consciousness and Management of Education for Sustainable Development Questionnaire (NCMESDQ), and analyzed using descriptive statistics and Pearson Correlation. The results revealed that there were positive and significant relationships between cultural integration, sports activities, gender equality and management of secondary education for sustainable development in Nigeria. The findings imply that education managers should improve cultural integration by finding more common grounds in the cultural practices of the people in respect to dressing, festivals and the likes, furthermore, education managers should pay more emphasis on sport activities as a means of bringing students of various schools together as well as improve on gender equality in order to maintain effective management of secondary education for sustainable development in Nigeria.

Keywords: National consciousness, cultural integration, gender equality, sports activities, sustainable development

\footnotetext{
${ }^{1}$ Department of Educational Management, Faculty of Education, University of Ilorin, Nigeria Email: abdullahi.njk@unilorin.edu.ng

2 Department of Educational Management, Faculty of Education, University of Ilorin, Nigeria Email: isiaka.ba@unilorin.edu.ng

${ }^{3}$ Department of Educational Management, Faculty of Education, University of Ilorin, Nigeria Email: atolagbe.aa@unilorin.edu.ng

${ }^{4}$ Department of Educational Management, Faculty of Education, University of Ilorin, Nigeria Email: neematkadir@yahoo.co.uk
} 


\section{Introduction}

The great challenge facing Nigeria today is the lack of national integrity which has hindered the Nigerian efforts to advance because of inequitable distribution of public facilities which has created many problems such as conflicts social unrest, riots, Boko haram issues, insurgency, bandicts, ethnic intolerance, religion fundamentalists and the likes to terrorize the Nigerian States (Jacob \& Andrew, 2015). Therefore, to keep country at crossroads in terms of development and achieving true national programmes and policies, we need undiluted national consciousness in forms of cultural integration, gender equality and appropriate sports activities to enhance effective management of education in order to remain a united, reliable, respected and dependable nation.

National consciousness is now generally accepted as the most effective approach for appropriate management of education for sustainable development (Otwin, 2008). Good understanding of the culture of Nigerian people will greatly prevent multitudinous of ethnic based conflicts, which have currently pervaded the country. Actually, lack of effective capacity to manage these accumulations of problems has continued to sustain this stormy moment. Therefore, there is need to learn from the past and correct the imbalances inherent in the country by being able to determine the present circumstances and possibly anticipate national consciousness and sustainable development in the future.

Secondary education plays important roles in making an individual to be self-developed and self-reliant towards developing the nation. Secondary education is described as the education children receive after basic education and before tertiary education. It is at this stage of education that learners are prepared for tertiary institution such as colleges of education, polytechnics and universities. According to the framework of secondary schools according to National Policy on Education (2013) is that it shall last for six years and broken into two distinct parts that are perfectly related (junior and senior secondary education).

Numerous studies have been conducted on national consciousness and management education. Udoye et al (2014) examined the factors that hinder Elearning among Igbo language teachers: Implication for national consciousness. Sample of 20 Igbo teachers were selected. The findings revealed that most indigenous language teachers are not conversant with E-learning. Ibaba (2009) carried out education and national integration in Nigeria. Mustapha et al (2018) treatise has a focus on effectiveness on promoting kindergarten curriculum for national consciousness. Adebola (2007) carried out implication of universal basic education on national development. Eimuhi and Gladys (2015) conducted a study about fundamental issues in the management of secondary education in 
Nigeria. Oguzie (2014) investigated guidance and counseling services as a coping strategy for inculcating consciousness of peace, conflict resolution and national security among secondary school youth in Anambra State, Nigeria. Sample of 127 counsellors were selected. Data were analyzed using mean score and standard deviation. The findings revealed that effective utilization of guidance and counselling services inculcated in the youth the spirit of consciousness that promote peace, conflict resolution and national security. There are several areas on national consciousness and education that are yet to be discussed by these scholars. These areas include national consciousness and management of secondary education for sustainable development in Nigeria. In addition, to the researchers' knowledge, there have been no researches in Nigeria so far that looked at cultural integration, gender equality and sports activities as critical variables to measure national consciousness. Therefore, this study endeavor to fill the gaps left by the previous scholars.

\subsection{Objectives of the Study}

The following objectives have been formulated to:

1. Investigate the relationship between cultural integration and management of secondary education for sustainable development.

2. Examine the relationship between gender equality and management of secondary education for sustainable development

3. Determine the relationship between sports activities and management of secondary education for sustainable development

\subsection{Research Hypotheses}

The following hypotheses were formulated and tested:

1. There is no significant relationship between cultural integration and management of secondary education for sustainable development.

2. There is no significant relationship between gender equality and management of secondary education for sustainable development.

3. There is no significant relationship between sports activities and management of secondary education for sustainable development

\subsection{Significance of the Study}

The findings of this study will be of great advantage to government, teachers, principals and stakeholders in education. The findings of this study will help the government and stakeholders to understand the importance of cultural integration, gender equality, sports activities so as to ensure effective management of education for sustainable development. Also, this study would serve as a useful guide and reference point for further researchers in the field of education. 


\section{Literature Review}

National consciousness is the awareness that one belongs to an ethnic or political group with the aim of sustaining the norms and interest, giving substantial economic support to the nation, defence against external threat and internal division, obedience to constituted authority as well as initiating and espousing ideas that can foster meaningful transformation, growth and development (Oguzie, 2014). This implies that, the interest of the nation comes before individual preferences. It also refers to the level of a person's awareness of issues and happening in the nation and how they affect him/her and others in the nation (Udoye et al, 2014). It is the love and affection for oneself and selfawareness that transforms to self-consciousness. National consciousness refers to cultural integration, gender equality and sports activities for effective management of secondary education towards sustainable development.

Cultural integration is the process of inclusion of aspiration, norm, value and attitude in the institution and relation of the host society. Peoples and Bailey (2019) defined cultural integration as a process of gradually bringing tangible and intangible cultural aspects of people together. Cultural integration is of great important for effective management of school and maintenance of sustainable development (Kania, 2010). A variation of cultures coexists in the country and many of them might be entirely new and strange to students. Therefore, government should find ways of integrating those cultures in education system toward achieving sustainable development. Cultural integration is a critical

principle to the components of the value chain and overall realization of sustainable development (Reidy, 2010).

Gender equality is the condition that gives girls and boys equal benefits and enjoyment of resources, human rights and social value goods as well as potential opportunities to gain from and contribute to the development of society politically, socially, economically and culturally (Verloo, 2005). Gender equality refers to an approach where measures are put in place to compensate for historical bias and discrimination that prevent boys and girls from operating on a level playing ground (Tobias, 2017). Equality does not mean that boys and girls will become the same but their rights, responsibilities, needs and interests are taken into consideration without any discrimination.

Sports activities play a vital role in human life from the very inception of the civilized world. Sports activities are educational tools to educate an individual's body through body movement. Everybody in this world must get full opportunities in accordance with his natural tradition of sports for practicing physical fitness and attaining a level of achievement in sports. Therefore, special opportunities must be created for young people to develop their personalities and 
relationship with others through sports suited to their requirement or age. Sports activities develop students' abilities and discipline to be fully integrated member of the society (Ibrahim et al, 2016).

Effective management can be seen as proper planning, coordinating, organizing and utilization of both human and material resources available in order to realize optimal result within the organisation (Abdullahi et al., 2016). Osarenren-Osaghae (2013), defined educational management as the process of mobilizing and systematic arrangement of human and material resources within a school for effective teaching and learning towards the achievement of school goals and objectives. This implies that principal and government should endeavor to provide adequate and standard facilities in secondary schools.

Development is a way of transforming individuals, households, communities, public as well as private institutions through building of human capacities to ensure effective utilization of available resources towards economic and societal improvements (Babalola, 2013). Sustainable development refers to the development that meets the needs of the present without making the future generation worse off (Abdullahi \& Jimoh, 2019). Sustainable development is a process of maintaining variety of opportunities that will help individuals and communities achieve their full potential and improving the economic, social and environmental system over a sustained period of time (Munasinghe, 2004). It can also be seen as a process of improving the quality of life and increase the selfsufficient capacity of individual towards global integration (Willis, 2005; Tadaro \& Smith, 2003).

The theoretical frame work of this study is based on Maslow's hierarchy of needs theory as cited in Abdullahi (2017). Maslow suggested five levels of human needs raging from low level needs to high level needs. Low level needs are externally satisfied (physiological needs and safety needs) while high level needs are internally satisfied needs (social needs, esteem need and selfactualization needs). The hierarchy of needs identified by Maslow in ascending order includes physiological needs (food, cloth, shelter, sex, sleep and so on), safety needs, social or love need (belongingness), esteem needs (achievement, status, prestige) and self-actualization needs (self-fulfillment, peak experience among others). This theory can be applied in the management of secondary education in that lower order needs which are physiological needs such as food, shelter, sex, warmth, clothing and safety needs in terms of safety from unfavorable environment, and the like can be catered for through effective cultural integration, gender equality and sports activities while higher order needs such as love needs (belongingness, work group), esteem needs (recognition, power, self-respect, self-regard, good reputation, fame, social 
success, status, prestige) and self-actualization needs (in terms of fulfillment of one's dreams, ambition and aspiration) can be achieved by providing effective management of secondary schools toward achieving sustainable development in Nigeria. This study is anchored on the system theory because effective attainment of sustainable development depends largely on the national consciousness in terms of cultural integration, gender equality as well as sports activities for effective management of secondary education.

\subsection{Research Design}

\section{Research Methodology}

Quantitative research design was used in this study. The design was considered appropriate because it helped the researchers to determine the collaboration that exist between national consciousness and management of secondary education for sustainable development. It also gave the chance to get view of the sample population, analyzed the data collected with the use of appropriate data analysis technique and reached a rational conclusion about the population from the findings of the study (Creswell \& Creswell, 2017).

\subsection{Population and Sampling}

This study focused on public secondary schools in Kwara State, Nigeria. There are 310 public senior secondary schools in Kwara State. The target population of this study comprised of 310 principals and 6,894 teachers in public senior secondary schools in Kwara State. Sample of 175 principals and 364 teachers were selected with the use of Research Advisor (2006) table of determining sample size of a known population making a total of 539 participants.

Table 3.1

\begin{tabular}{llcccc}
\multicolumn{6}{c}{ Population and Sample Size of Principals and Teachers in Kwara State } \\
\hline S\# & $\begin{array}{l}\text { Senatorial } \\
\text { Districts }\end{array}$ & $\begin{array}{l}\text { Total number } \\
\text { of principals }\end{array}$ & $\begin{array}{l}\text { Sample } \\
\text { Principals }\end{array}$ & $\begin{array}{l}\text { Total number } \\
\text { of teachers }\end{array}$ & $\begin{array}{l}\text { Sample } \\
\text { Teachers }\end{array}$ \\
\hline 1. & Kwara Central & 82 & 46 & 1023 & 54 \\
2. & Kwara North & 108 & 61 & 2307 & 122 \\
3. & Kwara South & 120 & 68 & 3564 & 188 \\
& Total & 310 & 175 & 6894 & 364 \\
\hline
\end{tabular}

Proportional sampling technique was used to select sample of 175 principals and 364 teachers across the three senatorial districts, this involves obtaining the population of principals and teachers in each selected secondary school in the three senatorial districts in Kwara State and selecting the sample proportionally from these population as shown in table 3.1. Stratified random sampling technique was used to select principals and teachers from the sample 
schools in order to ensure that all categories of principals and teachers were given equal chance of being selected.

\subsection{Instrumentation}

The research instrument for the this study comprised of self-administered questionnaires titled "National Consciousness Questionnaire (NCQ)" and adapted questionnaire on Management of Secondary Education for Sustainable Development Questionnaire (MSESDQ). A total number of 15 items were used to measure national consciousness with three subscales: cultural integration (5 items), gender equality ( 5 items) and sports activities (5 items). The items of questionnaire regarding management of secondary education for sustainable development was concluded from Abdullahi (2016) on planning with (5 items), coordinating (5 items) and organizing (5 items). Participants replied to four-point Likert scale ( $4=$ strongly agree; $3=$ agree; 2 disagree; $1=$ strongly disagree). The criterion mean is given thus: $4+3+2+1 / 4=2.50$. The criterion mean depicts that any item that is above or equal to the criterion mean value of 2.50 is agreed while the one below the criterion mean value is disagreed by the respondent. Dolnicar and Grun (2007) conclude that 4-point Likert scale answer format was easier to complete and faster than 5 and 7-point scales.

\subsection{Validity and Reliability}

To ensure the content validity of the instrument, draft copies of the instruments were given to two experts in educational management and two experts in measurement and evaluation. Relevant amendments and change were made based on their observations and recommendations. Also, 20 corrected copies were further administered to principals and teachers who were part of the samples to examine their clearness of the items of the wording, instructions and comprehensibility of the scales and questions in order to determine if there are any difficulties that may arise in filling the questionnaire. Therefore, some suggestion made were corrected properly before sending out concluding copies. To test the reliability of the items, Cronbach's alpha test was used. As shown in Tables 3.2 and 3.3, the value for Cronbach's alpha for this study was proven to be acceptable.

Table 3.2

Reliability Test for National Consciousness

\begin{tabular}{llc}
\hline Variables & $\mathrm{n}$ & Cronbach's Alpha \\
\hline Cultural integration & 5 & 0.82 \\
Gender equality & 5 & 0.83 \\
Sports activities & 5 & 0.82 \\
\hline
\end{tabular}

Table 3.2 shows that there are 5 items under cultural integration of national consciousness. The value of the Cronbach's Alpha for the 5 items under 
cultural integration is 0.82 . It further shows that there are 5 items under gender equality with Cronbach's Alpha of 0.83 and 5 items under sports activities with Cronbach's Alpha of 0.82. According to Brannen (2017), values above 0.7 are considered acceptable and values above 0.8 are preferable and represent a good reliability. Therefore, the Cronbach's Alpha value for all the 3 indicators of national consciousness were around 0.82 . Therefore, the values show very good internal consistency reliability for scale and all the 15 items in the questionnaire are found to be consistent.

Table 3.3

Reliability Test for Management of Secondary Education for Sustainable Development

\begin{tabular}{llc}
\hline \multicolumn{1}{c}{ Variables } & $\mathrm{n}$ & Cronbach's Alpha \\
\hline Planning & 5 & 0.84 \\
Coordinating & 5 & 0.82 \\
Organizing & 5 & 0.80 \\
\hline
\end{tabular}

Table 3.3 shows the 3 main indicators of management of secondary education for sustainable development. These are planning, coordinating and organizing. The Cronbach's value for planning is 0.84 covering up to 5 number of items. In addition, 5 items from coordinating have Cronbach's Alpha Value of 0.82 and 5 items from organizing has Cronbach's Alpha Value of 0.80. In summary, all instrument items for management of secondary education for sustainable development used in this study are reliable.

\subsection{Data Collection}

The researcher with the help of two research assistants personally administered the instruments to the principals and teachers of the sample senior secondary schools. The questionnaire was distributed to over 580 participants consisting of selected principals and teachers in public senior secondary schools. These participants were contacted in their respective offices to discuss the basis of the study before the distribution of the questionnaire. After 2 weeks, all the answered questionnaires were retrieved from the participants. However, a total of 542 questionnaires were returned and filled properly. Therefore, the returned number meet the suggestion of Research Advisor (2006) with a number of 539 participants sample in this study. The participants were assured on ethical issues by promising confidentiality and anonymity of their responses (Stanley \& Wise, 2010).

\section{Data Analysis and Interpretation}

The data collected for the study were analyzed using descriptive statistics including mean and standard deviation to determine the objectives of the study. 
Inferential statistics Pearson product moment correlation coefficient statistic for the hypotheses at (0.5) level of significance was applied to determine the rejection or acceptance of the hypotheses. This section discusses the result of the findings. The findings were organized based on research objectives.

\subsection{Cultural Integration}

Objective 1: to determine the relationship between cultural integration and management of secondary education for sustainable development.

Table 4.1 presents the mean and standard deviation of data collected from 175 principals and 364 teachers in public senior secondary schools in Kwara State, Nigeria.

Table 4.1

\section{Cultural Integration}

\begin{tabular}{|c|c|c|c|c|c|c|}
\hline \multirow[t]{2}{*}{ S\# } & \multirow[t]{2}{*}{ Cultural Integration } & \multicolumn{2}{|c|}{$\begin{array}{l}\text { Principals' } \\
\text { Responses }\end{array}$} & \multicolumn{2}{|c|}{$\begin{array}{l}\text { Teachers' } \\
\text { Responses }\end{array}$} & \multirow[t]{2}{*}{ Decision } \\
\hline & & Mean & SD & Mean & SD & \\
\hline & $\begin{array}{l}\text { helps students to respect individual worth } \\
\text { and human dignity. }\end{array}$ & 2.95 & 0.916 & 2.90 & 0.959 & Agreed \\
\hline & $\begin{array}{l}\text { promotes functioning of democracy in the } \\
\text { country. }\end{array}$ & 2.90 & 0.964 & 2.82 & 0.977 & Agreed \\
\hline & $\begin{array}{l}\text { helps to tolerate and appreciate cultural and } \\
\text { religion differences. }\end{array}$ & 2.93 & 0.968 & 2.87 & 0.992 & Agreed \\
\hline & $\begin{array}{l}\text { helps in having respect for natural } \\
\text { resources. }\end{array}$ & 2.88 & 1.018 & 2.77 & 1.047 & Agreed \\
\hline & $\begin{array}{l}\text { helps students to identify their duties and } \\
\text { responsibilities as a citizen by appreciating } \\
\text { others. }\end{array}$ & 2.83 & 1.013 & 2.90 & & Agreed \\
\hline & Grand Mean & 2.89 & 0.976 & 2.85 & 1.004 & \\
\hline
\end{tabular}

As shown in Table 4.1, the overall perception of the principals and teachers on the cultural integration is interpreted as "Agreed" $(\mathrm{M}=2.89, \mathrm{SD}=$ $0.976)$ and $(\mathrm{M}=2.85, \mathrm{SD}=1.004)$. This shows that the principals and teachers agreed that cultural integration enhance effective management of secondary education for sustainable development in Kwara State, Nigeria. In addition, all the responses obtained mean values higher than the criterion mean value of 2.50. This shows that the principals and teachers agree that cultural integration i) helps students to respect individual worth and human dignity. $(\mathrm{M}=2.95, \mathrm{SD}=0.916)$ and $(\mathrm{M}=2.90, \mathrm{SD}=0.959)$, ii) promotes functioning of democracy in the country $(\mathrm{M}=2.90, \mathrm{SD}=0.964)$ and $(\mathrm{M}=2.82, \mathrm{SD}=0.977)$, iii $)$ helps to tolerate and appreciate cultural and religion differences. $(\mathrm{M}=2.93, \mathrm{SD}=0.968)$ and $(\mathrm{M}$ $=2.87, \mathrm{SD}=0.992)$, iv) helps in having respect for natural resource $(\mathrm{M}=2.88$, $\mathrm{SD}=1,018)$ and $(\mathrm{M}=2.77, \mathrm{SD}=1.047), \mathrm{v})$ helps students to identify their duties 
and responsibilities as a citizen by appreciating others $(\mathrm{M}=2.83, \mathrm{SD}=1.013)$ and $(\mathrm{M}=2.90, \mathrm{SD}=1.027)$.

\subsection{Gender Equality}

Table 4.2 shows the analysis of the samples' response for the construct of gender equality and management of secondary education for sustainable development.

Table 4.2

Gender equality as Responded by Participants

\begin{tabular}{|c|c|c|c|c|c|c|}
\hline \multirow[t]{3}{*}{ S\# } & \multirow{3}{*}{ Gender Equality } & \multirow{2}{*}{\multicolumn{2}{|c|}{$\begin{array}{l}\text { Principals' } \\
\text { Responses }\end{array}$}} & \multirow{2}{*}{\multicolumn{2}{|c|}{$\begin{array}{l}\text { Teachers' } \\
\text { Responses }\end{array}$}} & \multirow{3}{*}{ Decision } \\
\hline & & & & & & \\
\hline & & Mean & SD & Mean & SD & \\
\hline & $\begin{array}{l}\text { promotes harmonization of work and } \\
\text { responsibility. }\end{array}$ & 2.90 & 0.962 & 2.76 & 0.959 & Agreed \\
\hline & $\begin{array}{l}\text { eliminates all forms of discrimination that } \\
\text { hinders effective management of } \\
\text { education. }\end{array}$ & 2.95 & 0.918 & 2.94 & 0.963 & Agreed \\
\hline 3. & strengthens national unity and integration & 2.95 & 0.966 & 2.93 & 0.983 & Agreed \\
\hline & $\begin{array}{l}\text { promotes lifelong learning and } \\
\text { opportunities for all. }\end{array}$ & 2.86 & 1.020 & 2.79 & 1.047 & Agreed \\
\hline & $\begin{array}{l}\text { promotes healthy lives and well-being for } \\
\text { all at all age. }\end{array}$ & 2.84 & 1.004 & 2.98 & 0.971 & Agreed \\
\hline & Grand Mean & 2.90 & 0.974 & 2.88 & 0.985 & \\
\hline
\end{tabular}

As shown in Table 4.2, the overall perception of the principals and teachers on the gender equality is interpreted as "Agreed" $(\mathrm{M}=2.90, \mathrm{SD}=$ $0.974)$ and $(\mathrm{M}=2.88, \mathrm{SD}=0.985)$. This shows that the principals and teachers agreed that gender equality bring about effective management of secondary education for sustainable development in Kwara State, Nigeria. In addition, all the responses obtained mean values higher than the criterion mean value of 2.50. This shows that the principals and teachers agree that gender equality i) promotes harmonization of work and responsibility $(\mathrm{M}=2.90, \mathrm{SD}=0.962)$ and $(\mathrm{M}=2.76$, $\mathrm{SD}=0.959)$, ii) eliminates all forms of discrimination that hinders effective management of education $(\mathrm{M}=2.95, \mathrm{SD}=0.918)$ and $(\mathrm{M}=2.94, \mathrm{SD}=0.963)$, iii) strengthens national unity and integration $(\mathrm{M}=2.95, \mathrm{SD}=0.966)$ and $(\mathrm{M}=$ 2.93, $\mathrm{SD}=0.983)$, iv) promotes lifelong learning and opportunities for all $(\mathrm{M}=$ $2.86, \mathrm{SD}=1,020)$ and $(\mathrm{M}=2.79, \mathrm{SD}=1.047), \mathrm{v})$ promotes healthy lives and well-being for all at all age $(\mathrm{M}=2.84, \mathrm{SD}=1.004)$ and $(\mathrm{M}=2.98, \mathrm{SD}=0.971)$. 


\subsection{Sports Activities}

Table 4.3 shows the analysis of the samples' response for the construct of sports activities and management of secondary education for sustainable development.

Table 4.3

Sports Activities as Responded by Participants

S\#

Sports Activities

\begin{tabular}{|c|c|c|c|c|}
\hline \multicolumn{2}{|c|}{$\begin{array}{l}\text { Principals' } \\
\text { Responses }\end{array}$} & \multicolumn{2}{|c|}{ Teachers' } & \multirow[t]{2}{*}{ Decision } \\
\hline Mean & $\overline{\mathrm{SD}}$ & Mean & SD & \\
\hline 2.88 & 0.940 & 2.93 & 0.961 & Agreed \\
\hline 3.02 & 0.886 & 2.98 & 0.921 & Agreed \\
\hline 2.95 & 0.965 & 3.03 & 0.931 & Agreed \\
\hline 2.95 & 0.965 & 3.02 & 0.928 & Agreed \\
\hline 2.95 & 0.981 & 3.05 & 0.905 & Agreed \\
\hline 2.95 & 0.949 & 3.00 & 0.929 & \\
\hline
\end{tabular}

As shown in Table 4.3, the overall perception of the principals and teachers on the sports activities is interpreted as "Agreed" $(\mathrm{M}=2.95, \mathrm{SD}=$ $0.949)$ and $(\mathrm{M}=3.00, \mathrm{SD}=0.929)$. This shows that the principals and teachers agreed that sports activities enhance effective management of secondary education for sustainable development in Kwara State, Nigeria. In addition, all the responses obtained mean values higher than the criterion mean value of 2.50. This shows that the principals and teachers agree that sports activities i) promotes and develops interpersonal skills among children which makes the students socially adjusted in all type of situation $(\mathrm{M}=2.88, \mathrm{SD}=0.940)$ and $(\mathrm{M}=2.93$, $\mathrm{SD}=0.961)$, ii) helps to introduce an element of joy and recreation into academically oriented environment $(\mathrm{M}=3.02, \mathrm{SD}=0.886)$ and $(\mathrm{M}=2.98, \mathrm{SD}=$ $0.921)$, iii) improves students awareness of well-being $(\mathrm{M}=2.95, \mathrm{SD}=0.965)$ and $(\mathrm{M}=3.03, \mathrm{SD}=0.931)$, iv) teaches the value of maintaining good health (M $=2.95, \mathrm{SD}=0.975)$ and $(\mathrm{M}=3.02, \mathrm{SD}=0.928), \mathrm{v})$ helps to shape character and promotes overall personality development $(\mathrm{M}=2.95, \mathrm{SD}=0.981)$ and $(\mathrm{M}=3.05$, $\mathrm{SD}=0.905)$. 


\section{Hypothesis Testing}

$\mathrm{H}_{01}$ There is no significant relationship between cultural integration and management of secondary education for sustainable development.

Table 4.4

Cultural Integration and Management of Secondary Education for Sustainable Development

\begin{tabular}{|c|c|c|c|}
\hline Cultural Integration & $\begin{array}{c}\text { Pearson } \\
\text { correlation }\end{array}$ & 1 & $.820^{* *}$ \\
\hline \multirow{5}{*}{$\begin{array}{l}\text { Management of } \\
\text { Education for } \\
\text { Sustainable } \\
\text { Development }\end{array}$} & $\begin{array}{c}\text { Sig. } \\
\text { (2-tailed) }\end{array}$ & & .000 \\
\hline & $\mathrm{N}$ & 539 & 539 \\
\hline & $\begin{array}{l}\text { Pearson } \\
\text { Correlation }\end{array}$ & $.820^{* *}$ & 1 \\
\hline & $\begin{array}{c}\text { Sig. } \\
\text { (2-tailed) }\end{array}$ & .000 & \\
\hline & $\mathrm{N}$ & 539 & 539 \\
\hline
\end{tabular}

Table 4.4 indicates that cultural integration has a positive and significant relationship with management of secondary school for sustainable development with calculated $\mathrm{r}$-value $=.820 ; \mathrm{p}<.000$. This shows that there is a significant and positive relationship between cultural integration and management of secondary education for sustainable development. Thus, the hypothesis which states that there is no significant relationship between cultural integration and management of secondary education for sustainable development is rejected (Ary et al., 2010). $\mathrm{H}_{02}$ : There is no significant relationship between gender equality and management of secondary education for sustainable development.

Table 4.5

Gender Equality and Management of Secondary Education for Sustainable Development

\begin{tabular}{|c|c|c|c|}
\hline Gender Equity & $\begin{array}{c}\text { Pearson } \\
\text { correlation }\end{array}$ & 1 & $.810^{* * *}$ \\
\hline \multirow{5}{*}{$\begin{array}{l}\text { Management of } \\
\text { Education for } \\
\text { Sustainable } \\
\text { Development }\end{array}$} & $\begin{array}{c}\text { Sig. } \\
\text { (2-tailed) }\end{array}$ & & .000 \\
\hline & $\mathrm{N}$ & 539 & 539 \\
\hline & $\begin{array}{c}\text { Pearson } \\
\text { Correlation }\end{array}$ & $.810^{* *}$ & 1 \\
\hline & $\underset{\text { (2-tailed) }}{\text { Sig. }}$ & .000 & \\
\hline & $\mathrm{N}$ & 539 & 539 \\
\hline
\end{tabular}


Table 4.5 indicates that gender equity has a positive and significant relationship with management of secondary school for sustainable development with calculated $\mathrm{r}$-value $=.810 ; \mathrm{p}<.000$. This shows that there is a significant and positive relationship between gender equity and management of secondary education for sustainable development. Thus, the hypothesis which states that there is no significant relationship between gender equity and management of secondary education for sustainable development is rejected (Cresswell, 2015).

$\mathrm{H}_{03}$ : There is no significant relationship between sports activities and management of secondary education for sustainable development.

Table 4.6

\section{Sports Activities and Management of Secondary Education for Sustainable} Development

\begin{tabular}{lcll}
\hline Sports activities & Pearson correlation & 1 & $.870^{* *}$ \\
\hline & Sig. & & .000 \\
& (2-tailed) & 539 & 539 \\
Management of & Pearson Correlation & $.870^{* *}$ & 1 \\
Education for & & & \\
Sustainable & & & \\
Development & & &
\end{tabular}

Sig. $\quad .000$

(2-tailed)

$\mathrm{N} \quad 539 \quad 539$

Table 4.6 indicates that sports activities have a positive and significant relationship with management of secondary school for sustainable development with calculated $\mathrm{r}$-value $=.870 ; \mathrm{p}<.000$. This shows that there is a significant and positive relationship between sports activities and management of secondary education for sustainable development. Thus, the hypothesis which states that there is no significant relationship between sports activities and management of secondary education for sustainable development is rejected (A. Mugenda \& O. Mugenda, 2013).

\section{Discussion and Conclusion}

The findings of study show that cultural integration enhance effective management of secondary education for sustainable development in Kwara State, Nigeria, such that it helps students to respect individual worth and human dignity, promoting functioning of democracy in the country, tolerating and appreciating cultural and religious differences, help students to have respect for natural resources as well as helping students identify their duties and responsibilities as a citizen. Results from hypothesis one indicated that there is significant relationship between cultural integration and 
management of secondary education for sustainable development in Kwara State, Nigeria. This finding agreed with Reidy (2010) and Godman (2007) that cultural integration serve as a component for overall achievement of sustainable development. This finding also conformed to Peoples and Bailey (2019) and Yusuf (2013) that cultural integration can be instrumental for enhancing effective management of education for sustainable development.

The findings in Table 4.5 shows that gender equality bring about effective management of secondary education for sustainable development in Kwara State, Nigeria. These are, gender equality promotes harmonization of work and responsibility, eliminates all forms of discrimination that hinder effective management of education, strengthens national unity and integration, promotes life-long learning and opportunities for all as well as promote healthy lives and well-being for all at all age. Result from hypothesis two analysis showed that there is significant and positive relationship between gender equality and management of secondary education for sustainable development. The findings of this conformed to Tobias (2017) that gender equality contribute to effective management of education for sustainable development of a country. This study agreed with Verloo (2005) that gender equality gives opportunities for both genders to contribute to the development of society politically, socially, economically and culturally.

The findings in Table 4.6 show that sports activities enhance effective management of secondary education for sustainable development in Kwara State, Nigeria. These are, sports activities promote and develops interpersonal skills among children, help to introduce an element of joy and recreation into academically oriented environment, improve students' awareness of well-being, teaches the value of maintaining good health as well as shape the character and promotes overall personality development. Result from hypothesis three analysis showed that there is significant relationship between sports activities and management of secondary education for sustainable development.

Based on the findings of this study, the researchers concluded that there were positive and significant relationship between the three indicators of national consciousness (cultural integration, gender equality and sports activities) and management of secondary education for sustainable development as they were found to correlate one another.

\section{Recommendations}

1. Education managers should ensure effective cultural integration in school so as to help students respect individual worth and human dignity, promoting 
functioning of democracy in the country, tolerating and appreciating cultural and religious differences, help students have respect for natural resources as well as helping students identify their duties and responsibilities as a citizen.

2. Education managers may improve on gender equality in order to promote harmonization of work and responsibility, eliminate all forms of discrimination that hinder effective management of education, strengthen national unity and integration, promote life-long learning and opportunities for all as well as promote healthy lives and well-being for all at all age.

3. Education managers may also pay more emphasis on sport activities as a means of bringing students of various schools together so as to promote and develop interpersonal skills among children, help to introduce an element of joy and recreation into academically oriented environment, improve students awareness of well-being, teaches the value of maintaining good health as well as shape the character and promotes overall personality development.

\section{References}

Abdullahi, N. J. K. (2017). Managing universal basic education for breaking poverty circle in Nigeria. Kampala International University Journal, 2(2A), 39-46.

Abdullahi, N. J. K., \& Jimoh, A. K. G. (2019). Head Teachers' Role in Managing Science Education towards Sustainable Development in North-Central Zone, Nigeria. Malaysian Online Journal of Educational Science (MOJES), 6(3), 20-29.

Abdullahi, N. J. K., Musa, R. M., \& Mayachi, M. L. (2016). Managing education for sustainable peace and national development: Focus on principals' managerial roles in Kwara State, Nigeria. International Journal of Tropical Education Issue. 1(1), 35-43.

Adebola, O. J. (2007). Perceived impact of universal basic education on national development. Journal of African American Studies, 1(1), 49-58.

Ary, D., Jacobs, L. C., \& Sorensen, C. (2010). Introduction to research in education $\left(8^{\text {th }}\right.$ ed.). California: Thomson Wadsworth. 
Babalola, J. B. (2013). Education for sustainable development in Africa. Keynote address delivered at UCC-Unilorin Joint International Conference, Ghana.

Brannen, J. (2017). Mixing methods: Qualitative and quantitative research. Retrieved from https://www.taylorfrancis.com/books/9781351917186

Cresswell, J. W. (2015). A concise introduction to mixed methods research. Thousand Oaks, California: SAGE.

Cresswell, J. W., \& Creswell, J. D. (2017), Research Design: Qualitative and mixed methods approach. USA: Sage Publications.

Dolnicar, S., \& Grun, B. (2007). User-Friendliness of answer format-An empirical comparison. Australasian Journal of Market and Social Research, 15(1), 19-28.

Eimuhi, J. O., \& Gladys, O. B. (2015). Fundamental issues in the management of secondary education in Nigeria. Journal of Emerging Trends in Educational Research and Policy Studies, 6(7), 265-270.

Godman, L. W. (2007). Principles of CT and CT technology. Journal of nuclear medicine technology, 35(3), 115-128.

Ibaba, S. I. (2009). Education and national integration in Nigeria. Journal of Research in National Development, 7(2), 56-67.

Ibrahim, T. O., Bakinde, S. T. \& Aina, M. G. (2016). Pedagogy as science, technology and art of teaching. In A. A. Adegoke, R. A. Lawal, A.G.A.S. Oladosu \& A. A. Jekayinfa (eds.). Introduction to teaching methodology. Haytee Press and Publishing Company Nigeria Ltd, Ilorin Kwara State, Nigeria.

Jacob, O., \& Andrew, A. O (2015). Terrorism and insecurity in Nigeria: Moral, Value, and religion education as panaceas. Journal of Education and Practice, 6(11), 120-126.

Kania, S. M. (2010). The role of cultural differences in forming a business strategy. Journal of Intellectual Management, 2(2), 16-25. 
Mugenda, A., \& Mugenda, O. (2013). Research methods: Quantitative and qualitative approaches. Nairobi: ACTS Press.

Munasinghe, S. (2004). Effective instructions through dynamic discipline. Ohio, Charles, Merill.

Mustapha, F. A., Ali, M. A., Nawaf, S. A., \& Mu'stasen, M. A. (2018). Effectiveness of three types of kindergarten curricula in promoting national consciousness among the Jordanian kindergarten children. International Journal of humanities and Social Sciences, 8(11), 65-74. doi:10.30845/ijhss.v8n11p8

National policy on education (2013). Federal Ministry of Education. Yaba, Lagos: Nigeria.

Oguzie, N. (2014). Guidance and counselling services as a copping strategy for inculcating consciousness of peace, conflict resolution and national security among secondary school youth in Anambra State, Nigeria. International Multidisciplinary Journal, Ethiopia, 8(2), 256-279.

Osarenren-Osaghae, R. I. (2013). Organisation and management of secondary education. In Eunice, O. O. \& Don, O. (Ed.). Organization of Education in Nigeria. Independent Concept: Benin City, Edo State.

Otwin, M. (2008). National service and national consciousness in Nigeria. Journal of Modern African Studies, 17(4), 629-654.

Peoples, J. \& Bailey, B. S. (2019). Humanity: An introduction to cultural anthropology. Wadsworth: Wadsworth, Cengage Learning.

Reidy, R. W. (2010). Intercultural awareness: the new value chain principle. Journal of Intercultural Management, 2(1), 57-68.

Research Advisor (2006). Sample size table. http://www.reseach-advisor.com

Stanley, L., \& Wise, S. (2010). The ESRC's 2010 Framework for Research Ethics: fit for research purpose? Sociological Research Online, 15(4), 12-13.

Tobias, G. (2017). An overview of issues and concepts in gender mainstreaming. Afro Asian Journal of Social Science, 8(1), 1-21.

Todaro, M. P. \& Smith, S. C. (2003). Economic Development $\left(8^{\text {th }}\right.$ ed.). Harlow: Pearson Education Limited. 
Udoye, I., Akpamgbo, U. \& Asimuonye, A. (2014). Factor that hinders Elearning among Igbo language teachers: Implication for national consciousness. Research on Humanities and Social Science, 4(27), 28-32.

Verloo, M. (2005). Mainstreaming gender equality in European: A framework analysis approach. The Greek Review of Social Research, 117,11-34.

Willis, K. (2005). Theories and practices of development. London: New York Routledge.

Yusuf, H. O. (2013). Promoting peaceful co-existence and religion tolerance through supplementary readers and reading comprehension passages in basic education curriculum. International Journal of Humanities and Social Sciences, 3(8), 224-234.

\section{Citation of this Article:}

Kadir, A. N. J., Akanmu, I. B. Adetiba, A. A., \& Ovigueraye, E. P. A. (2021). National Consciousness and Management of Secondary Education for Sustainable Development in Kwara State, Nigeria. International Journal of Innovation in Teaching and Learning (IJITL), 7(2), 1-18. 